\title{
A Study of Urban Form and the Integration of Energy Supply Technologies
}

\author{
Vicky Cheng ${ }^{1, *}$, Sandip Deshmukh ${ }^{2}$, Anthony Hargreaves ${ }^{1}$, Koen Steemers ${ }^{1}$, Matthew Leach ${ }^{2}$ \\ ${ }^{1}$ Department of Architecture, University of Cambridge, Cambridge CB2 1PX, UK \\ ${ }^{2}$ Centre for Environmental Strategy, University of Surrey, Guildford GU2 7XH, UK \\ * Corresponding author. Tel: +44 1223762549, Fax: +44 1223332960,E-mail: bkc25@cam.ac.uk
}

\begin{abstract}
Buildings account for a substantial share of the energy consumption and $\mathrm{CO}_{2}$ emissions in the UK. Reduction of energy consumption and the use of low carbon technologies in buildings constitute a vital part in achieving the government's $\mathrm{CO}_{2}$ reduction goals. Based on six existing urban form examples in the UK, this paper explores the potential for integrating different low carbon technologies for buildings taking into account factors relate to built forms. The study suggests that dwelling density has a significant influence on energy demand; however, it is not the only factor that influences the potential for low carbon energy supply. The combination of dwelling density and site coverage are the crucial built form factors that determine the potential of $\mathrm{CO}_{2}$ reductions from low carbon technologies. The initial findings suggest that medium to low density housing may in some cases enable a greater saving in $\mathrm{CO}_{2}$ emissions than higher density development because of the greater amount of space for collection of renewable energy. However, the effects of density on the energy use by other sectors such as transport, water and waste management, also needs to be considered and this integrated approach is part of our ongoing research on the ReVISIONS project.
\end{abstract}

Keywords: Urban Form, Integrated Energy Supply, Renewable Energy, Low Carbon Technologies

\section{Introduction}

Buildings in the residential, commercial and public sectors account for an estimated $48 \%$ of the total final energy consumption and $42 \%$ of all carbon emissions in the UK. The UK government has made a commitment in the Climate Change Act 2008 that the carbon account for the year 2050 is to be at least $80 \%$ lower than the 1990 baseline [1]. Reduction of energy consumption and the use of low carbon technologies in buildings constitute a vital part in achieving the government's carbon emission reduction goals. The Code for Sustainable Homes [2] requires that new homes are zero carbon by 2016. However, the rate of new house building in the UK is less than $1 \%$ per year compared to the existing housing stock and so around two thirds of the housing stock of 2050 already exists. Therefore, a substantial reduction in the carbon emissions from the existing housing stock is vital for achieving carbon reduction targets.

Energy use in buildings can be attributed to three main factors: building design, systems performance and occupant behaviour. Building design parameters such as plan, section, orientation and façade design account for a $2.5 \mathrm{x}$ variation in energy consumption. Services system parameters such as the efficiencies of lighting, boiler and other equipments contribute a $2 \mathrm{x}$ variation and occupant behaviour for a $2 \mathrm{x}$ variation. These factors cumulatively lead to a total variation of tenfold in energy consumption of buildings with similar functions [3]. Clearly, the design of built form and service systems has significant energy implications; they not only influence the energy demand but also determine the potential for renewable energy supply and the use of low carbon technologies. The government has committed to delivering $15 \%$ of energy from renewables by 2020 in accordance with the European Union Renewables Directive [4]. In order to achieve this goal, a significant increase of small-scale to communityscale renewable electricity and heat generation is expected [5]. The UK government launched a consultation in 2009 on its Heat and Energy Saving Strategy [6] which proposed that by 2030 all homes would have received a 'whole house' package including all cost effective energy saving measures plus renewable heat and electricity measures as appropriate. The policies are still tentative at this stage because there are a range of uncertainties about how 
these measures will be implemented. There are some exploratory ongoing schemes such as the Carbon Emissions Reduction Target 2009-2012 (CERT) and the Community Energy Saving Programme 2009-2012 (CESP) which place obligations on energy supply companies to reduce carbon emissions and improve energy efficiency. The aim is to achieve a $30 \%$ reduction in carbon emissions from households by 2020 compared to 2006. However, there are a number of uncertainties about how large scale retrofitting of existing dwellings can be achieved and guidance is required on what measures are appropriate and cost effective for different urban forms and densities.

Many of the energy-efficient and renewable energy technologies available today (such as solar thermal, photovoltaic, micro-wind turbine, heat pumps, CHP, etc.) have already been in development for several decades; we have profound understanding of the science and engineering of these technologies. However, our knowledge concerning the integration and optimization of these technologies in buildings with respect to built form and spatial layout is limited. In the current planning practice, the decision about the built form for a particular target density is often driven by a combination of economic, social and cultural factors. The final form however would ultimately govern the potential of renewable energy sources that could be exploited on-site. In order to deliver a sustainable low carbon development, the design of built form, its energy implications and the potential for renewable and low carbon technologies needed to be considered together with other non-environmental factors in an integrated manner.

This study explores the potential for integrating different low carbon microgeneration technologies for buildings taking into account factors relate to built forms and spatial layouts. This paper represents our first step in understanding the interaction between energy demand and the supply technologies. This work forms part of the ReVISIONS project ${ }^{1}$, a wider study investigating the inter-relationship between spatial planning and infrastructure policies for transport, water, waste and energy at the regional and local scales.

\section{Existing urban form examples}

Six existing urban form examples in Cambridge and London in the UK are selected for this study (Figure 1). The examples are largely domestic areas built up from Census output areas. Census output areas are statistical geography developed by the Office for National Statistics (ONS) as part of the 2001 Census in the UK; they are generated in consideration of population size, mutual proximity and social homogeneity. Land use information in each of the example area is sourced from General Land Use Database (GLUD) and the number of dwellings and dwelling type data are sourced from Neighbourhood Statistics Database.

The six urban form examples exhibit a diversity of densities and morphologies:

1. Comprises mainly rows of two-storey terrace houses at a gross residential density ${ }^{2}$ of 55 dph. Each dwelling has its own private garden but communal open space is scarce in close vicinity. This setting is commonly found in many urban residential areas in England.

2. Comprises mainly detached and semi-detached houses at a density of $18 \mathrm{dph}$; this setting is typical of suburban areas where dwelling density is low and the dwelling plot size is large.

\footnotetext{
${ }^{1}$ ReVISIONS Regional visions of integrated sustainable infrastructure optimized for neighbourhoods project website: http://www.regionalvisions.ac.uk

2 The residential density measure used throughout this paper is expressed in dwelling per hectare (dph) and is the gross density within selected Census output areas of predominantly residential use. It is calculated as the ratio of total number of dwellings to entire selected site area; the measure of site area takes into account all land use types (e.g. domestic, nondomestic, road, green space, etc.)
} 
3. Is characterized by a courtyard-form layout which comprises mainly four-storey terrace houses and flats at a density of $33 \mathrm{dph}$. This spatial arrangement results in large areas of communal open space whilst private garden area is limited.

4. Represents a mixed urban form at a density of $27 \mathrm{dph}$. It has semi-detached houses with large private garden in the west, courtyard-form apartment blocks with communal open space in the east and rows of terraced houses in the middle.

5. Comprises a ten-storey courtyard-form apartment block which houses over 1200 flats; it has a very high density of $523 \mathrm{dph}$. Although primarily domestic, the development contains spaces for other uses: however this paper focuses on the built form of dwellings and does not consider non-domestic spaces.

6. Consists of three distinctive built forms: a fifteen-storey high-rise tower ( 181 dph), a cluster of terraced houses ( $\sim 93 \mathrm{dph})$ and a group of multi-storey slab-block flats ( $\sim 97 \mathrm{dph})$. The entire study area has a gross residential density of $100 \mathrm{dph}$. The high density and diverse spatial arrangements may give rise to the potential of communal infrastructures for low carbon energy generation.

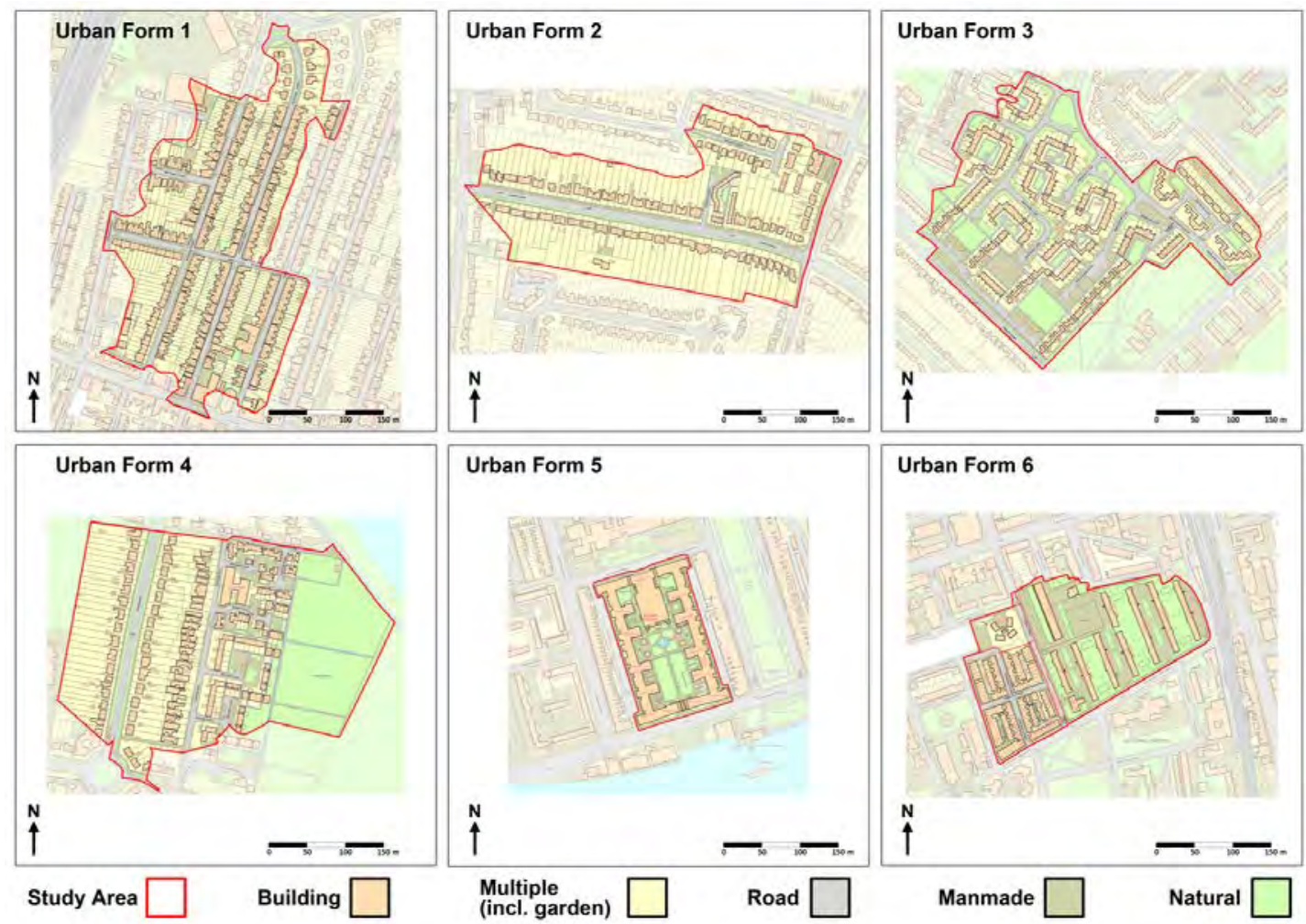

Fig. 1. The six urban form examples selected for this study (shown on the same scale).

(C) Crown Copyright/ database right 20(10). An Ordnance Survey/EDINA supplied service.

\section{Domestic energy demand}

The domestic energy demand of each urban form example is estimated using the Domestic Energy and Carbon Model (DECM) developed as part of the ReVISIONS project [7]. DECM consists of two major components: a housing stock database and a building energy model. The housing stock database is primarily developed based on the English House Condition Survey 2007. The survey contains 16194 sample dwellings covering a range of typical domestic building types in England. The building energy model is based on SAP-2005 with modifications to improve the energy estimation. DECM incorporates regional climate data and performs monthly calculations for electricity, water heating and space heating demands. Comparison of the model prediction with national statistics published by the UK Department 
of Energy and Climate Change (DECC) confirms the capability of DECM in providing good estimations at both national and Local Authority (LA) levels. At national level, the model estimation of $\mathrm{CO}_{2}$ emissions and gas and electricity consumptions are respectively $4.5 \%$, $3.4 \%$ and $1.0 \%$ higher than the DECC figures. At the LA level, the correlations between the model estimations and the DECC records are statistically significant and substantial (all $\mathrm{r}_{\mathrm{s}}>0.9$ and $\left.\mathrm{p}<.01\right)$.

Using DECM, average dwelling energy demand and $\mathrm{CO}_{2}$ emissions for the four main dwelling types are produced (Table 1$)^{3}$. The heat and electricity demands for each urban form example are estimated by multiplying these figures by the corresponding number of dwellings in each example. This method assumes the energy demand of dwellings in the urban form examples do not significantly deviate from the national averages. This is a rough estimation because the occupancies per dwelling will vary locally depending on the supply and demand for housing in different areas. Table 2 summarizes the key building parameters and estimated energy demand of each example area. It shows that energy demand per dwelling decreases with increased gross residential density $\left(\mathrm{r}_{\mathrm{s}}=-0.829, \mathrm{p}<.05\right)$. It is mainly due to the changes in dwelling mix; more flats and fewer houses at high density and vice versa in low density. This observation is consistent with a wider analysis conducted by the main author based on national housing stock and domestic energy consumption statistics.

Table 1. Annual average dwelling energy demand and $\mathrm{CO}_{2}$ emissions for four main dwelling types

\begin{tabular}{|c|c|c|c|c|}
\hline & Detached & Semi-detached & Terraced House & Flat \\
\hline Floor area $\left(\mathrm{m}^{2}\right)$ & 137.7 & 94.4 & 85.4 & 62.2 \\
\hline Occupants (number) & 2.6 & 2.5 & 2.5 & 1.8 \\
\hline \multicolumn{5}{|l|}{ Energy demand (kWh) } \\
\hline Space heating & 14064 & 10490 & 9553 & 5547 \\
\hline Water heating & 2469 & 2010 & 1901 & 1590 \\
\hline Electricity & 3949 & 3105 & 2932 & 2320 \\
\hline $\mathrm{CO}_{2}$ emissions $^{4}$ (tonnes) & 7.4 & 5.7 & 5.3 & 4.0 \\
\hline
\end{tabular}

Table 2. Key building parameters and estimated annual energy demand of each urban form example

\begin{tabular}{|c|c|c|c|c|c|c|}
\hline Urban Form & 1 & 2 & 3 & 4 & 5 & 6 \\
\hline Site area (ha) & 8.0 & 8.3 & 8.1 & 9.3 & 2.4 & 4.8 \\
\hline Gross density (dph) & 55 & 18 & 33 & 27 & 523 & 100 \\
\hline Site coverage ${ }^{5}$ & 0.3 & 0.1 & 0.2 & 0.2 & 0.5 & 0.3 \\
\hline \multicolumn{7}{|c|}{ Dwelling mix (number) } \\
\hline Detached & 20 & 40 & 8 & 34 & 0 & 3 \\
\hline Semi-detached & 42 & 64 & 25 & 70 & 0 & 0 \\
\hline Terraced & 322 & 18 & 159 & 39 & 0 & 51 \\
\hline Flat & 55 & 29 & 73 & 110 & 1236 & 426 \\
\hline Total & 439 & 151 & 265 & 253 & 1236 & 480 \\
\hline \multicolumn{7}{|l|}{ Energy demand (kWh) } \\
\hline Water heating & 833294 & 307712 & 488298 & 473674 & 1965438 & 781755 \\
\hline Space heating & 4103152 & 1566740 & 2298678 & 2195206 & 6855780 & 2892334 \\
\hline Electricity & 1281106 & 476748 & 744790 & 721207 & 2868070 & 1149888 \\
\hline Energy per dwelling & 14163 & 15571 & 13327 & 13400 & 9457 & 10050 \\
\hline $\mathrm{CO}_{2}$ emissions $^{6}$ & $2311 t$ & $870 \mathrm{t}$ & $1334 \mathrm{t}$ & $1293 t$ & $4925 t$ & $1990 \mathrm{t}$ \\
\hline
\end{tabular}

\footnotetext{
${ }^{3}$ Energy demand refers to the energy required to meet the various end-uses; it is different from energy consumption as the latter also takes into account system efficiency.

${ }^{4}$ Emission factors: gas $\left(0.184 \mathrm{kgCO}_{2} / \mathrm{kWh}\right)$, electricity $\left(0.47 \mathrm{kgCO}_{2} / \mathrm{kWh}\right)$, oil $\left(0.265 \mathrm{kgCO}_{2} / \mathrm{kWh}\right)$ and solid fuel $(0.333$ $\mathrm{kgCO}_{2} / \mathrm{kWh}$ ).

${ }^{5}$ Site coverage is calculated as the ratio of total domestic building footprint area to entire site area.

${ }^{6}$ Existing $\mathrm{CO}_{2}$ emissions (tonne/year) are estimated based on average dwelling emissions as shown in Table 1.
} 


\section{Urban form and low carbon energy generation technologies}

The low carbon energy technologies considered in this paper include solar thermal panel, photovoltaic (PV) panel, ground source heat pump (GSHP) and combined heat and power (CHP) device. Table 3 provides a general view and the spatial requirements of these technologies [8]. Micro wind turbine is not considered in this study owing to the limited wind potential in urban areas.

Table 3. Low carbon technologies and their requirements

\begin{tabular}{|c|c|c|c|c|}
\hline Technology & Requirements & & $\begin{array}{l}\text { Typical cost } \\
\text { of one unit }\end{array}$ & $\begin{array}{l}\text { Typical size } \\
\text { in } \mathrm{kW}\end{array}$ \\
\hline Photovoltaics & $\begin{array}{l}\text { Roof or space } \\
\text { facing SE/SW }\end{array}$ & $\begin{array}{l}\text { Can export electricity if connected } \\
\text { to grid, more cost effective if high } \\
\text { on-site demand }\end{array}$ & $\begin{array}{l}£ 5 \mathrm{k} \text { to } £ 25 \mathrm{k} \\
\text { upwards }\end{array}$ & $\begin{array}{l}1 \text { to } 4 \\
\text { upwards }\end{array}$ \\
\hline Solar thermal & $\begin{array}{l}\text { Roof or space } \\
\text { facing SE/SW }\end{array}$ & Hot water demand on-site & $£ 2 \mathrm{k}$ to $£ 5 \mathrm{k}$ & 2 to 3 \\
\hline $\begin{array}{l}\text { Ground } \\
\text { Source Heat } \\
\text { Pump }\end{array}$ & $\begin{array}{l}\text { Land area for } \\
\text { ground collector } \\
\text { or a water } \\
\text { source }\end{array}$ & $\begin{array}{l}\text { Building with a space heating } \\
\text { (and possibly cooling) demand } \\
\text { and low temperature heating } \\
\text { system (e.g. under-floor) }\end{array}$ & $\begin{array}{l}£ 5 \mathrm{k} \text { to } £ 25 \mathrm{k} \\
\text { upwards }\end{array}$ & $\begin{array}{l}3.5 \mathrm{~kW} \text { to } 15 \\
\mathrm{~kW} \text { upwards }\end{array}$ \\
\hline $\begin{array}{l}\text { Micro-CHP } \\
\text { and CHP }\end{array}$ & $\begin{array}{l}\text { Domestic or } \\
\text { communal } \\
\text { space }\end{array}$ & $\begin{array}{l}\text { Proportional heat and electricity } \\
\text { demand, scope for heat network }\end{array}$ & $\begin{array}{l}£ 500 \text { to } 800 \\
/ \mathrm{kWe} \text { and } \\
£ 660 / \mathrm{kWe}\end{array}$ & $\mathrm{kW}$ to $\mathrm{MW}$ \\
\hline
\end{tabular}

The government has plan to significantly increase the uptake of low carbon and renewable energy technologies; the lead scenario set out in the RES suggests that over $30 \%$ of our electricity (including 2\% from small scale generation) and $12 \%$ of heat demand supplied by renewable sources [5]. Using the urban form examples, we examine the prospect of achieving these targets, the potential savings in $\mathrm{CO}_{2}$ emissions and cost effectiveness of the installations. Table 4 shows the proposed energy supply technology mix for each urban form example $^{7}$. The technologies are selected on the basis of economics (mainly costs), technological suitability (scale and scope), environmental (associated emissions), resource potential (availability), and social (acceptance and policy) factors. The proposed options are considered in conjunction with the national electricity grid so that surplus or shortage of electricity can be exported to or imported from the grid.

\footnotetext{
${ }^{7}$ The following assumptions are used in the calculation: solar thermal panel of typical 100 litre capacity requires $2.03 \mathrm{~m}^{2}$ of roof space; PV panel of 210 We capacity requires $1.64 \mathrm{~m}^{2}$ roof/facade space; and GSHP of $23.1 \mathrm{~kW}_{\text {th }}$ capacity. The heat and power ratios for micro-CHP and large-scale CHP are 3.0 and 1.8 respectively; they are assumed to be powered by gas and the overall efficiencies are $85 \%$ and $75 \%$ respectively. Excessive heat demand is assumed to be met by conventional gas boiler with efficiency $76 \%$.
} 
Table 4. Low carbon energy supply options for each urban form example

\begin{tabular}{|c|c|c|c|c|c|c|}
\hline Urban Form & 1 & 2 & 3 & 4 & 5 & 6 \\
\hline $\begin{array}{l}\text { Water } \\
\text { Heating } \\
\text { Demand } \\
\text { (kWh) }\end{array}$ & $\begin{array}{c}\text { Solar thermal: } \\
437 \text { panels of } \\
100 \text { (lit) } \\
\text { capacity }\end{array}$ & $\begin{array}{c}\text { Solar } \\
\text { thermal: } 148 \\
\text { panels of } \\
100 \text { (lit) } \\
\text { capacity }\end{array}$ & $\begin{array}{c}\text { Micro-CHP: } \\
488298\end{array}$ & $\begin{array}{l}\text { Micro-CHP: } \\
\text { 340400; } \\
\text { GSHP: } \\
133274\end{array}$ & $\begin{array}{c}\text { CHP: } \\
1965438\end{array}$ & $\begin{array}{l}\text { CHP: } \\
781755\end{array}$ \\
\hline $\begin{array}{l}\text { Space Heating } \\
\text { Demand } \\
\text { (kWh) }\end{array}$ & $\begin{array}{l}\text { GSHP: } \\
4158000 ; \\
\text { electricity } \\
\text { required: } \\
864000\end{array}$ & $\begin{array}{l}\text { GSHP: } \\
\text { 1663200; } \\
\text { electricity } \\
\text { required: } \\
345600\end{array}$ & $\begin{array}{c}\text { Micro-CHP: } \\
1746072\end{array}$ & $\begin{array}{l}\text { GSHP: } \\
\text { 2195206; } \\
\text { electricity } \\
\text { required: } \\
483840\end{array}$ & $\begin{array}{c}\text { CHP: } \\
3197088\end{array}$ & $\begin{array}{c}\text { CHP: } \\
\text { 1288043; } \\
\text { GSHP: } \\
\text { 1663200; } \\
\text { electricity } \\
\text { required: } \\
345600 \\
\end{array}$ \\
\hline $\begin{array}{l}\text { Electricity } \\
\text { Demand } \\
\text { (kWh) }\end{array}$ & PV: 1026205 & PV: 720804 & $\begin{array}{l}\text { Micro-CHP: } \\
744790\end{array}$ & $\begin{array}{c}\text { PV: 691619; } \\
\text { Micro-CHP: } \\
\text { 113467 } \\
\end{array}$ & $\begin{array}{c}\text { CHP: } \\
2868070\end{array}$ & $\begin{array}{c}\text { CHP: } \\
1149888\end{array}$ \\
\hline $\begin{array}{l}\text { Renewable/ } \\
\text { low carbon } \\
\text { supply }\end{array}$ & $\begin{array}{c}6017498 \\
\text { kWh }\end{array}$ & $\begin{array}{c}2691716 \\
\text { kWh }\end{array}$ & $\begin{array}{c}2979160 \\
\text { kWh }\end{array}$ & $3473966 \mathrm{kWh}$ & $\begin{array}{c}8030596 \\
\text { kWh }\end{array}$ & $\begin{array}{c}4823977 \\
\text { kWh }\end{array}$ \\
\hline $\begin{array}{l}\text { Other supply } \\
\text { (kWh) }\end{array}$ & $\begin{array}{c}\text { Grid elect.: } \\
1118901\end{array}$ & $\begin{array}{l}\text { Grid elect.: } \\
101543\end{array}$ & $\begin{array}{c}\text { Gas: } \\
4232007\end{array}$ & $\begin{array}{c}\text { Grid elect.: } \\
399961 \\
\text { Gas: } 533961\end{array}$ & $\begin{array}{c}\text { Gas: } \\
20399786\end{array}$ & $\begin{array}{l}\text { Grid elect.: } \\
345600 \\
\text { Gas: } \\
6431969 \\
\end{array}$ \\
\hline $\begin{array}{l}\text { Renewable/ } \\
\text { low carbon }\end{array}$ & $84 \%$ & $96 \%$ & $41 \%$ & $79 \%$ & $28 \%$ & $42 \%$ \\
\hline $\begin{array}{l}\mathrm{CO}_{2} \text { savings } \\
\text { (tonnes/year) }\end{array}$ & 1757 & 777 & 409 & 943 & 325 & 381 \\
\hline $\begin{array}{l}\text { Capital \& } \\
\text { operations } \\
\text { costs } \\
\end{array}$ & $£ 9.1 \mathrm{M}$ & $£ 5.1 \mathrm{M}$ & $£ 0.8 \mathrm{M}$ & $£ 5.0 \mathrm{M}$ & $£ 2.7 \mathrm{M}$ & $£ 3.7 \mathrm{M}$ \\
\hline $\begin{array}{l}\text { Effective costs } \\
\text { ( }\left(/ \mathrm{tCO}_{2} \text { saved) }\right.\end{array}$ & $£ 259$ & $£ 328$ & $£ 98$ & $£ 265$ & $£ 416$ & $£ 486$ \\
\hline
\end{tabular}

\section{Discussion and Conclusion}

The fraction of total energy demand which can be supplied by renewable and low carbon technologies varies remarkably from $28 \%$ to $96 \%$ across the six urban form examples; the variation is dependent of built form as exhibited in different dwelling types. Houses in general provide more opportunities for the application of low carbon technologies (especially renewable technologies) as they have suitable roof and garden areas where natural energy can be harvested. Urban Form 1 and 2 with high proportion of houses in the dwelling mix facilitate the use of solar thermal, PV and GSHP and result in the highest proportions of renewable and low carbon supplies. The spatial layout of apartment buildings significantly limits the exploitation of renewable energy; the strategy of low carbon supply lies on efficient cogeneration of heat and electricity. The high concentration of energy demand and the generally high proportion of heat to electricity demand in apartment buildings are conducive to the use of cogeneration systems. As illustrated in Urban Form 5, assuming a 20-year lifetime for the CHP system, an estimated 258 tonnes of $\mathrm{CO}_{2}$ can be saved on average annually by switching the conventional centralized energy supplies to a cogeneration system; the saving is equivalent to around $6 \%$ of the total emissions produced by the existing centralized system to 2030 . 
The capital and operational costs of the proposed technology mix for each urban form example vary widely from less than $£ 1$ million to $£ 9$ million. The high costs shown in Urban Form 1, 2 and 4 are mainly due to the use of PV panels. The use of PV technology, although seemingly expensive, results in remarkable reduction in $\mathrm{CO}_{2}$ emissions. Table 5 presents an alternative energy supply option for Urban Form 1, 2 and 4 where the use of PV is excluded; the demand for water heating is provided by solar thermal systems and space heating provided by GSHP. The entire electricity demand is assumed to be met by the national grid.

In order to gain a fuller picture of the cost effectiveness of the proposed technology mix, the effective costs which represent the costs per tonne of $\mathrm{CO}_{2}$ saved are examined. The effective costs are calculated based on an average 20-year lifetime of the technologies applied in conjunction with the UK government projection of the carbon dioxide emission factors for different fuels for 2030 [9]. The government expects to see a substantial reduction of coalfired power plants and a considerable increase of renewable sources in the national electricity generation in 2030. As a result, the emission factor of grid electricity is projected to fall from the current $0.47 \mathrm{kgCO}_{2} / \mathrm{kWh}$ to $0.19 \mathrm{kgCO}_{2} / \mathrm{kWh}$ in 2030 ; whilst for fuels other than electricity, the emission factors are assumed to remain constant to 2030.

\begin{tabular}{|c|c|c|c|}
\hline & 1 & 2 & 4 \\
\hline Renewable/ low carbon supply & $\begin{array}{c}4991294 \\
(70 \%)\end{array}$ & $\begin{array}{c}1970912 \\
(71 \%)\end{array}$ & $\begin{array}{c}2802154 \\
(70 \%)\end{array}$ \\
\hline $\mathrm{CO}_{2}$ savings (tonnes/year) & 1401 & 527 & 767 \\
\hline Capital \& operations costs & $£ 4.1 \mathrm{M}$ & $£ 1.5 \mathrm{M}$ & $£ 2.2 \mathrm{M}$ \\
\hline Effective costs ( $\left(\mathrm{E} / \mathrm{tCO} \mathrm{O}_{2}\right.$ saved) & $£ 145$ & $£ 144$ & $£ 143$ \\
\hline
\end{tabular}

As shown in Table 4, the effective costs vary between $£ 98$ and $£ 486$ for every tonne of $\mathrm{CO}_{2}$ saved across the urban form examples. The application of micro-CHP to supply all of the electricity and heating for Urban Form 3 results in the option with the lowest cost per tonne of $\mathrm{CO}_{2}$ saved but uses gas which not renewable and this technology will become less cost effective as gas supplies become scarcer and more expensive. The proposed technology mix for Urban Forms 5 and 6 is the least cost effective because communal CHP at this scale of application works out more expensive than the micro-CHP used for Urban Form 3. On the other hand, the technologies for Urban Forms 1, 2 and 4 are relatively expensive but achieve a much greater reduction in $\mathrm{CO}_{2}$ emissions and are therefore more cost effective per tonne of $\mathrm{CO}_{2}$ saved than Urban Forms 5 and 6. The complete elimination of direct fossil fuel use in the proposed technology mix for Urban Form 1, 2 and 4 derive the most benefits from the government's decarbonisation strategy for grid electricity but the cost per tonne saved is far greater than the 2030 value of $£ 70$ per tonne of carbon mitigation by DECC [10]. Table 5 shows that if PV is omitted from the technology mix for Urban Forms 1, 2 and 4 then the cost per tonne of $\mathrm{CO}_{2}$ saved is substantially reduced but is still around twice the DECC value. These renewable energy technologies may become better value for money if their costs can be reduced and if grid electricity can be decarbonised to a greater extent than assumed in this paper. The above comparisons suggest that the most cost effective building-scale technologies are those that supply heat. Further research is now being carried out by our ReVISIONS project on how these low carbon technologies could function as part of wider systems and how technologies such as CHP may become more cost effective when considered at a wider communal scale. This research will continue to focus on how urban spatial form affects the feasibility of these technologies. 
Dwelling density has a significant influence on energy demand per household; however, it is not the only factor that influences the potential for low carbon energy supply. For instance, Urban Form 1 is more than three times as dense as Urban Form 2 but both show high potential for the application of these renewable and low carbon technologies. The combination of both dwelling density and site coverage are the crucial built form factors that determine the potential reductions in carbon emissions from these technologies. The small number of urban form examples recruited in this study limited the feasibility of a quantitative analysis of the effects of morphological parameters such as site coverage and plot ratio on the potential of low carbon supply. The examples shown in this paper suggest that medium to low density housing may in some cases enable a greater saving in carbon emissions than higher density development because of the greater amount of space for collection of renewable energy. However, the effects of density on the energy use by other sectors such as transport, water and waste management, also needs to be considered and this integrated approach is part of our ongoing research on the ReVISIONS project.

\section{Acknowledgements}

Research for this paper was supported by funding from the UK's Engineering and Physical Science Research Council (EPSRC) for the project entitled 'ReVISIONS: Regional Visions of Integrated Sustainable Infrastructure Optimised for NeighbourhoodS'.

\section{References}

[1] H.M. Government, Climate Change Act 2008, 2008.

[2] Department for Communities and Local Government (CLG), The code for sustainable homes: setting the standard in sustainability for new homes, 2008.

[3] Baker, N. and K. Steemers, Energy and environment in architecture: a technical design guide, E. \& F. N., 2000.

[4] European Union Renewables Directive, Official Journal of the European Union L140/16: on the promotion of the use of energy from renewable sources, 2009.

[5] H.M. Government, UK Renewable Energy Strategy, 2009.

[6] Department of Energy and Climate Change (DECC), Heat and energy saving strategy consultation: executive summary, 2009.

[7] Cheng, V. and K. Steemers, Modelling domestic energy consumption at district scale: A tool to support national and local energy policies, Environmental Modelling and Software (submitted for review) 2010.

[8] Enviros Consulting Limited, Utilising renewable energy resources within south Cambridgeshire, 2008.

[9] Market Transformation Programme (MTP), BNXS01: Carbon dioxide emission factors for UK energy use: version 4.2, 2010.

[10]Department of Energy and Climate Change (DECC), Carbon valuation in UK policy appraisal: a revised approach (June 2010 update), 2010. 